\title{
PENGEMBANGAN KNOWLEDGE MANAGEMENT BERBASISKAN TALENT MANAGEMENT UNTUK MENDUKUNG KNOWLEDGE CULTURE
}

\author{
Hery Harjono Muljo \\ Jurusan Akuntansi, Fakultas Ekonomi dan Komunikasi, BINUS University \\ Jln. K.H. Syahdan No 9, Palmerah, Jakarta Barat 11480 \\ heryhm@binus.edu
}

\begin{abstract}
Every organization needs to realize that the inside knowledge should be used efficiently and effectively, and also should get support from knowledge culture. The purpose of the writing is the development of knowledge management based on talent management to support the existence of knowledge culture. The method used is through survey, interview, direct observation and literature study. Survey and interview had been done in Talent Management BINUS University, especially in Learning and Department $(L \& D)$ unit. The direct observation is through key performance indicator of lecturers. The literature study is through exploring scientific journals, especially related to the topic of knowledge management through website. The result is that it could be concluded in strategy of policy and award rewarded used to approach knowledge management development in supporting knowledge culture.
\end{abstract}

Keywords: knowledge culture, talent management, management knowledge

\begin{abstract}
ABSTRAK
Setiap organisasi harus menyadari bahwa knowledge yang dimiliki di dalam perusahaan harus dapat dimanfaatkan secara efisien dan efektif dan juga harus dapat mendukung knowledge culture. Tujuan dari penulisan ini adalah mengembangkan knowledge management yang berbasiskan talent management guna mendukung tercipta knowledge culture. Metode yang digunakan survei, wawancara, pengamatan secara langsung dan studi literatur. Survei dan wawancara dilakukan di bagian Talent Management BINUS University khususnya unit Learning and Development (L\&D), Perfomance and Carreer Management (PCM), dan Employee Cominication. Pengamatan langsung dilakukan khusus pada key performance indicator dosen. Studi literatur dilakukan dengan cara penelusuran jurnal-jurnal ilmiah khususnya knowledge management yang berhubungan dengan topik melalui web. Simpulan yang dapat ditarik strategi dalam bentuk kebijakan dan pemberian award dapat digunakan sebagai cara untuk pendekatan pengembangan knowledge management mendukung knowledge culture.
\end{abstract}

Kata kunci: knowledge culture, talent management, management knowledge 


\section{PENDAHULUAN}

Secara umum knowledge management adalah mengelola knowledge karyawan dalam organisasi seefisien dan seefektif mungkin. Setiap organisasi perlu menyadari bahwa knowledge yang dimiliki di dalam perusahaan harus dapat dimanfaatkan secara efisien dan efektif untuk menciptakan layanan dan produk yang akan menarik khususnya untuk para pelanggan. Satu perusahaan dengan perusahaan yang berbeda akan memiliki knowledge berbeda. Untuk itu perusahaan harus dapat menggali knowledge yang dimiliki oleh karyawan secara maksimal (Hamid, 2008).

Bila knowledge yang dimiliki oleh karyawan tidak pernah dikembangkan, maka sangat disayangkan knowledge tersebut tidak dapat berkembang dan juga orang lain tak akan pernah tahu knowledge itu. Knowledge yang sudah di kelola dengan baik, dan mudah di akses akan sangat bermanfaat bagi orang lain guna menghindari kesalahan yang sama. Dalam mengelola knowledge, memerlukan pembedaan definisi untuk knowledge work. Menurut Nonaka \& Takeuchi (1995) knowledge diklasifikasikan menjadi 2 bagian yaitu tacit knowledge dan explicit knowledge. Menurut mereka explicit knowledge adalah sesuatu yang formal dan sistematis, yang dapat dinyatakan dalam kata dan angka yang dapat dilihat dan dibagi dalam bentuk tertulis atau nyata. Sedangkan tacit knowledge di sisi lain, didefinisikan sebagai yang bersifat intangible yang sulit untuk dibayangkan atau diekspresikan.

McAdam \& Reid (2000) menyebutkan bahwa transfer, menangkap (capture) dan penyebaran (disseminate) knowledge dan organisasi knowledge itu sendiri dianggap sebagai elemen kunci dari knowledge dan Knowledge Management. Industri menyadari bahwa knowledge para pekerja tidak hanya memanipulasi knowledge, mereka memperoleh, memodifikasi dan menciptakan pengetahuan yang akan bermanfaat bagi organisasi. Rangka mempertahankan keunggulan kompetitif di mana mereka dapat terus memenuhi kebutuhan yang selalu berubah dari klien mereka, perusahaan mulai menyadari kebutuhan untuk mengidentifikasi kemampuan pengetahuan para pekerjanya.

Setiap orang perlu menciptakan budaya berbagi. terkadang pengetahuan dipandang sebagai kekuasaan dan dalam lingkungan yang kompetitif mungkin ada kecenderungan untuk menimbun pengetahuan. Kunci keberhasilan knowledge management adalah penciptaan budaya berbagi pengetahuan dan penghapusan hambatan organisasi dan budaya untuk komunikasi. Kita harus pindah dari penimbunan pengetahuan untuk merebut kekuasaan menjadi berbagi pengetahuan untuk meraih kekuasaan.

Tujuan dari penulisan ini adalah mengembangkan knowledge management yang berbasiskan talent management guna mendukung tercipta knowledge culture sambil tetap menjaga knowledge culture selama perubahan.

Dalam mendukung knowledge culture, maka harus diperhatikan prinisp-prinsip knowledge culture antara lain orang lebih penting daripada sistem, publik mendukung knowledge sharing, anjuran dan dukungan praktek-praktek knowledge yang baik dan nilai-nilai adopsi dari semua anggota staf. Setelah knowledge dari para karwayan di dapat, bagaimana knowledge management dapat mendukung terciptanya knowledge culture. Untuk itu diperlukan strategi-strategi baru yang akan menjadi knowledge juga guna terbentuk knowledge culture dengan memperhatikan prinsip-prinsip knowledge culture. 


\section{METODE}

Metode yang digunakan dalam penulisan ini adalah survei, wawancara, pengamatan secara langsung dan studi literatur. Survei dan wawancara dilakukan di bagian Talent Management BINUS UNIVERSITY khususnya unit Learning and Development (L\&D), Perfomance and Carreer Management (PCM), dan Employee Cominication. Studi literatur dilakukan dengan cara penelusuran jurnal-jurnal ilmiah khususnya knowledge management yang berhubungan dengan topik melalui web.

\section{HASIL DAN PEMBAHASAN}

Berdasarkan hasil survei di beberapa bagian, terdapat beberapa cara pengembangan knowledge management berbasis talent management guna mendukung pembentukan knowledge culture antara lain Bina Nusantara Annual Quality Award, Create Sharing Knowledge, program induksi bagi karyawan baru maupun dosen, dan pelatihan.

\section{Key Performance Indicator (KPI) Dosen}

Setiap karyawan dan dosen pasti memiliki key performance indicator dalam menjalankan tugasnya atau sering disebut sebagai KPI. Tujuan dari KPI dijadikan sebagai alat ukur untuk mengukur ketercapaian kinerja baik unit maupun individu. Seluruh item-item penilaian KPI terdapat pada Performance Evaluation. KPI tiap unit merupakan turunan KPI dari atasannya. Rektor memiilki KPI, diturunkan ke para direktur dan dekan. Direktur dan dekan diturunkan ke level bawahnya lagi, yaitu ke para manager dan ke para kajur . KPI manager dan kajur diturunkan lagi ke section head dan ke sekjur dan dosen faculty member. KPI section head diturunkan lagi ke level bawahnya dan seterusnya. Bagi karyawan struktural yang merangkap dosen, maka individu tersebut memiliki 2 KPI yaitu KPI sebagai karyawan struktural maupun KPI sebagai dosen. Bagi hanya sebagai dosen saja, maka individu tersebut hanya memiliki KPI khusus dosen. Dosen yang dimaksud adalah faculty member.

Tiap dosen yang mengajar di perguruan tinggi wajib menjalankan TriDharma Perguruan Tinggi yaitu pengajaran, penelitian dan pengabdian. Pengajaran bagi dosen telah dijadwalkan setiap semester, tapi untuk penelitian, publikasi hasil penelitian dan pengabdian tidak terjadwal seperti pengajaran. Hal ini mengakibatkan rendahnya aktivitas dosen dalam meneliti, mempublikasikan hasil penelitian dan melakukan pengabdian.

Berdasarkan kendala di atas, diperlukan kebijakan khusus untuk mendorong meningkatkan jumlah penelitian, jumlah pubilkasi dan pengabdian kepada masyarakat. Kebijakan yang diambil adalah jumlah aktivitas penelitian, publikasi dan pengabdian dimasukan dalam KPI masing-masing dosen, dengan demikian tiap dosen sudah mengetahui berapa banyak penelitain yagn harus dihasilkan, berapa banyak publikasi yang harus dihasilkan dan juga berapa banyak kegiatan pengabdian yang harus dilakukan.

Untuk beberapa dosen faculty member tertentu KPI mereka adalah sama yaitu tiap faculty member wajib membuat proposal penelitian satu kali dalam setahun dan wajib mempublikasikan artikel hasil penelitian ke jurnal setiap semester dan wajib melakukan pengabdian kepada masyarakat 1 kali dalam setahun. Penugasan berdasarkan KPI telah berlangsung lama, yang awalnya agak sulit untuk diterapkan, cukup mengagetkan para dosen, dan berjalan kurang mulus. 
Selama masa perubahan, institusi harus dapat menjadi knowledge culture. KPI merupakan strategi yang diterapkan untuk mengukur performance evaluation bagi karyawan dan dosen tapi saat itu tidak mencakup penelitian, publikasi dan pengabdian. Penerapan KPI merupakan pemecahan masalah yang cukup sistematik, dan perubahannya juga sangat dinamis karena tidak terlalu membuat karyawan menjadi gelisah.

Setelah berjalan sekian lama, setiap dosen terbiasa dengan penugasannya berdasarkan KPI yang sudah disepakati. Pengumpulan artikel berjalan dengan lancar, tiap-tiap dosen faculty member telah sadar bahwa setiap semester harus mengumpulkan artikel, dan juga setiap setahun sekali terbiasa membuat dan mengumpulkan proposal penelitian. Berawal mengalami kesulitan dalam memperoleh hasil penelitian, publikasi dan pengabdian, kemudian diterapkan pada program KPI, dijalankan dengan beberapa rintangan, yang akhirnya terbentuklah sebuah culture terbiasa dengan mengajar, meneliti, mempublikasikan, dan pengabdian.

\section{Bina Nusantara Annual Quality Award}

Menurut Kuruganti (n.d.), salah satu cara menciptakan sharing knowledge culture adalah dengan cara meluruskan kembali insentif dan program hadiah. Orang tidak melakukan apa yang anda katakan kepada mereka, tetapi apa yang anda ukur terhadap mereka. Human Resources perlu untuk melembagakan sistem hadiah (reward) dan pengakuan (recognition), pelatihan dan praktek pengembangan kinerja kegiatan yang memperkuat disiplin berbagi, pendokumentasian pengetahuan dan penggunaan kembali gagasan orang lain dengan bangga untuk mencapai tujuan usaha.

Bina Nusantara Annual Quality Award yaitu program sukarela yang terbuka untuk Binusian dan merupakan salah satu bentuk upaya dari Talent Management guna mendapatkan terobosanterobosan baru atau ide-ide baru yang berasal dari bakat yang dimiliki para Binusian. Topik yang dipilih dapat berupa penjaminan mutu, efisiensi vs efektivitas, estetika, keuntungan organisasi, inovasi dan temuan, dengan memberikan reward kepada mereka yang menang.

Tiap peserta yang berpartisipasi harus mengirimkan makalahnya yang menjelaskan secara singkat mengenai topik yang diambilnya. Penjelasan tersebut meliputi pertama penjelasan aktivitas, kedua jangka waktu penyelesaian proyek, ketiga penjaminan mutu atau Inovasi yang dilakukan dengan implementasi Sistem Manajemen Mutu, keempat rincian program inovasi untuk mengubah paradigma termasuk metodologi (pendekatan), kelima data dan analisis yang terdiri dari sebelum implementasi program manajemen mutu termasuk menampilkan data dan analisa yang menunjukkan awal kinerja yang menjadi pertimbangan untuk membuat dan menentukan prioritas sasaran manajemen, dan setelah implementasi program manajemen mutu yang termasuk menampilkan data dan analisa pencapaian kinerja terhadap sasaran manajemen yang telah ditentukan dan memberikan rincian analisa dan tindakan yang diambil ketika gagal untuk mencapai sasaran tersebut, dan terakhir yang keenam adalah rangkuman.

Juri akan menilai semua makalah yang diserahkan oleh peserta dan memilih sepuluh finalis berdasarkan kriteria sebagai berikut pertama penjaminan Mutu atau Inovasi yang dilakukan mengubah paradigma departemen/unit dan memberi nilai tambah bagi BiNus, kedua rincian metode yang digunakan, ketiga metode analisa dan data, dan penilaian terakhir adalah hasil.

Setiap unit yang berpartisipasi pada program ini artinya unit tersebut telah mengalami peningkatan pemahaman atas pekerjaan yang dilakukan. Karena setiap unit yang mengusulkan usulan, wajib menerapkan terlebih dahulu usulannya di unit yang bersangkutan. Dengan demikian program ini merupakan bentuk program peningkatan unit yang merupakan bentuk inovasi mengembangkan unitnya. 
Program ini telah dijalankan sejak tahun 2007 dan berhasil menjaring banyak BINUSIAN. Penerapan program Bina Nusantara Annual Quality Award merupakan terobosan besar yang dilakukan Talent Management guna mengembangkan knowledge culture. Salah satu pendukung knowledge culture adalah core value yang terdiri dari Collaboration, Communication, Interaction, Innovation, Adaptation, Learning orientation, Trust, Knowledge is valued, dan Knowledge should be shared yang semuanya dipakai pada program ini. Bina Nusantara Annual Quality Award dapat dikatakan sebagai Best Practice bagi BINUS UNIVERSITY karena program ini merupakan sebuah terobosan baru, menghasilkan sesuatu yang lebih efektiv, efisien dan maksimal dan menghasilkan sesuatu yang bernilai, berharga dan dapat dijadikan sebagai panutan.

Dengan adanya program ini maka culture yang terbentuk adalah culture untuk selalu melakukan inovasi dan culture untuk berani bersaing untuk mendapatkan sesuatu yang terbaik yang berasal dari bakat masing-masing peserta. Keberhasilan penerapan knowledge culture ini dapat dilihat dari meningkatnya jumlah pendaftar yang mengikuti program quality award.

\section{Create Sharing Knowledge}

Banyak sekali knowledge yang dimiliki orang tiap orang yang terkadang tidak pernah dibagikan (sharing). Alangkah baiknya bila setiap knowledge yang dimiliki seseorang dapat dibagikan kepada orang lain yang secara tak langsung akan membantu orang lain saat mengalami hambatan.

Create sharing knowledge (CSK) merupakan program yang bertujuan untuk membagikan knowledge kepada sesama rekan Binusian. Program ini mulai diterapkan pada tahun 2005 khusus untuk Binusian level 6 sampai dengan Binusian level 9. Knowledge yang dibagikan (sharing) bisa berupa peraturan baru, hasil penelitian, hasil pelatihan yang pernah diikuti sebelumnya, dan juga penyaluran bakat-bakat yang dimiliki oleh para Binusian.

Para Binusian secara bergilir maju satu per satu setiap dua minggu sekali, dengan demikian bagi Binusian yang akan maju harus mempersiapkan bahan dan materinya, dan harus jelas knowledge apa yang ingin dibagikan ke sesama Binusian. Program ini merupakan program yang efektif untuk menyampaikan informasi, menyampaikan hasil penelitian, dan menyampaikan knowledge apapun kepada sesama Binusian.

Pada saat pelaksanaan kegiatan create sharing knowledge seluruh Binusian yang hadir dapat melakukan sharing dengan pemakalah. Bahkan para peserta yang hadir dapat juga memberikan masukan guna penyempurnaan apa yang disampaikan. Bila yang disampaikan adalah sebuah peraturan baru, maka hasil yang diperoleh dari seluruh peserta adalah peningkatan pemahaman atas sebuah pekerjaan.

Bagaimana create sharing knowledge dapat mendukung penerapan knowledge culture ? Culture yang dibentuk di BINUS saat tahun 2005 adalah Trust in God, Continuous Improvement, Benchmarking, Sense of closure, dan Sense of belonging. Create sharing knowledge merupakan bagian dari continuous improvement. Setiap Binusian diharapkan dapat secara terus menerus melakukan perbaikan, peningkatan (continuous improvement) guna mencapai visi misi yang telah ditetapkan. Program ini juga merupakan ajang tempat menampilkan seluruh bakat-bakat, ketrampilan hasil-hasil pengetahuan yang baru yang dimiilki oleh setiap Binusian. Dengan demikian create sharing knowledge merupakan salah satu strategi guna meningkatan knowledge yang akhirnya secara tak langsung merupakan penerapan knowledge culture. 


\section{Program Induksi}

Program induksi merupakan program yang ditujukan untuk karyawan baru. Latar belakang penerapan program induksi adalah bahwa setiap karyawan baru memerlukan pengetahuan tentang organisasi, budaya dan peraturan yang berlaku, dan juga setiap karyawan baru perlu mengetahui mengenai manfaat dan fasilitas yang ada selama menjadi karyawan. Tujuan dari program induksi ini adalah mengidentifikasi informasi yang benar mengenai institusi BINUS, mengenal visi, misi dan nilai-nilai BINUS, dapat menikmati setiap manfaat dan fasilitas yang disediakan oleh BINUS, dan beradaptasi dengan peraturan-peraturan BINUS.

Topik-topik yang disampaikan ke karyawan baru yaitu: (1) pengenalan BINUS, mengenai sejarah BINUS, BINUS Values, Visi Misi, Mars Binusian; (2) organizational structure; (3) pengenalan BINUS Quality Management; (4) pengenalan Talent Management Directorate; (5) pengenalan Employee Handbook; (6) pengenalan Human Resource Information System (HRIS); (7) pengenalan Performance Management System; (8) pengenalan Learning \& Development; (9) penjelasan Employee Benefits and Tax; (10) penjelasan Futzal Community, kesebelas fasilitas transportasi; dan (11) terakhir pengenalan BINUSIAN Card Flazz.

Program ini dilakukan di minggu pertama karyawan bekerja. Hal ini dilakukan dengan alasan sebelum karyawan baru bekerja maka mereka belum memahami seperti apa budaya BINUS, bagaimana peraturan yang berlaku, seperti apa sturktur organisasinya dan ketidaktahuan lainnya. Maka sebaiknya sebelum karyawan tersebut memulai pekerjaannya, mereka sebaiknya harus mengetahui terlebih dahulu pengetahuan tentang organisasi, budaya, peraturam, dan informasi lainnya.

Secara umum setiap orang yang baru bergabung pada satu perusahaan atau institusi untuk bekerja, rata-rata mereka memiliki komitmen, semangat dan motivasi yang tinggi. Selain itu juga mereka akan menyesuaikan diri untuk mengikuti setiap budaya yang ada, aturan main, dan juga selalu menuangkan ide-ide yang unik dan bermanfaat yang dapat digunakan untuk meningkatkan kinerja perusahaan tersebut. Dengan demikian itu merupakan kesempatan yang baik bagi BINUS untuk menerapkan program induksi untuk karyawan baru, dengan harapan menanamkan nilai-nilai budaya yang ada di BINUS, menselaraskan pemahaman dan pengertian visi misi BINUS, dan peraturanperaturan lainnya sehingga mereka dapat berpikir sejalan dan searah guna mencapai visi misi yang telah ditetapkan.

Maka dari itu program induksi ini dapat dikatakan sebagai strategi yang tepat bagi BINUS guna melakukan pendekatan dengan karyawan baru untuk membentuk mindset sesuai dengan budaya dan nilai-nilai BINUS, dan juga merupakan langkah tepat dalam mendukung penerapan knowledge culture.

\section{Pelatihan}

Salah satu konsentrasi BINUS dalam mencapai visi misi 2020 adalah pengembangan karyawan dalam bentuk pelatihan peningkatan kompetensi dan skill tertentu yang dimiliki oleh karyawan. Setiap karyawan di BINUS wajib mengikuti pelatihan. Jenis pelatihan terdiri dari pelatihan internal yang berarti instruktur pelatihan berasal dari BINUS, pelatihan eksternal yang berarti mengirimkan peserta ke luar BINUS, dan in-house training yang berarti mengundang nara sumber dari luar tapi tempat pelatihan di BINUS.

Proses perencanaan pelatihan di BINUS disiapkan di bagian Talent Management unit Learning and Development (L\&D). L\&D akan membuat analisis kebutuhan pelatihan (Training Need Analysis) berdasarkan skor Performance Evaluation dan usulan dari para manager di unit yang terkait. 
Performance evaluation menilai antara lain core competency dan technical competency. Core competency terdiri dari business acumen, customer orientation, leadership, adaptability, planning and organizing, meeting commitments, problem solving \& decision making, innovation/continuous improvement, teamwork/collaboration, people development, dan terakhir communication. Core competency tiap karyawan adalah sama, tapi proficiency level-nya berbeda tergantung dari grading dan tugas tanggung jawabnya. Setiap core competency dengan proficiency level tertentu akan memiliki beberapa key behavior yang merupakan perilaku-perilaku yang mencerminkan tingkat kompetensi. Berikut salah satu contoh core competency business acumen dengan proficiency level 1 dijabarkan dengan 5 key behavior yaitu: (1) recognizes business processes in his/her work unit; (2) aware of current organizational vision and missions; (3) describes work units goals with guidance from direct superior; (4) knows resources needed to achieve work units' goals; dan (5) aware of the need for cost efficiency.

Demikian juga technical competency, prinsipnya sama dengan core competency. Untuk technical competency, core competency yang dinilai terdiri dari 2 yaitu English proficiency, dan computer literacy. Core competency untuk technical competency setiap karyawan adalah sama, tapi proficiency level-nya yang berbeda. Setiap core competency dengan proficiency level tertentu akan memiliki beberapa key behavior. Berikut salah satu contoh untuk core competency English proficiency level 1 memiliki 2 key behavior yaitu listen and speaks in daily conversational English dan Listen, Speak, Read and write in simple vocational English context.

Berdasarkan hasil dari performance evaluation dan usulan dari para manager unit masingmasing, L\&D membuat analisa kebutuhan pelatihan (Training Need Analysis). Hasil dari analisa kebutuhan pelatihan kemudian dibuat topik-topik pelatihan, yang kemudian menghasilkan modulmodul pelatihan. Berdasarkan hasil analisa kebutuhan pelatihan itulah L\&D menentukan jenis pelatihan internal, eksternal atau in-house training yang akan diselenggarakan.

Pada tahun 2011 guna mencapai visi BINUS yaitu A World Class University In continuous pursuit of innovation and enterprise, BINUS telah melakukan pelatihan peningkatan bahasa inggris untuk seluruh karyawan termasuk dosen dan juga pelatihan computer. BINUS menetapkan standar minimum yang harus di capai baik keahlian bahasa inggris maupun computer. Sebelum mengikuti pelatihan setiap karyawan wajib mengikuti test guna menentukan apa saja yang perlu ditingkatkan.

Dilihat apa yang sudah dilakukan BINUS, maka BINUS telah menciptakan dan mempertahankan culture of continuous learning, dengan cara menciptakan kesempatan untuk belajar, belajar melalui pihak eksternal, belajar melalui pihak internal, menggunakan teknologi internet dalam proses pembelajaran, dan mengembangkan dan melatih karyawan. Demikianlah pengembangan knowledge management dalam bentuk pelatihan telah mendukung terciptanya knowledge culture.

\section{Kolokium}

Berawal dari kegiatan dosen dan mahasiswa strata dua untuk mempresentasikan usulan tesisnya. Setiap mahasiswa yang akan mengambil tesis wajib melakukan presentasi dihadapan para dosen pembimbing dan rekan-rekan mahasiswa. Di forum tersebut dosen dan mahasiswa yang turut hadir dapat bertanya dan memberikan saran dan masukan bagi pengusul tesis.

Dampak dari penyelenggaraan kolokium tersebut ternyata sangat bermanfaat khususnya para mahasiswa yang mengajukan usulan tesis, karena di forum tersebut pengusul tesis akan mendapatkan banyak sekali masukan-masukan guna penyempurnaan tesisnya. Melihat dampak yang positif tersebut, maka dikembangkanlah lingkup kolokium tidak hanya untuk mempresentasikan usulan tesis mahasiswa strata dua saja, tapi dapat juga untuk para dosen-dosen lain yang ingin mengusulkan usulan 
penelitian, paper yang akan diterbitkan ke jurnal, sharing ide-ide baru, atau sharing knowledge yang didapat saat seorang dosen ditugaskan workshop atau mengikuti pelatihan di luar.

Penyelenggaraan kolokium tersebut ternyata mendapat antusias yang cukup besar dari para dosen dengan harapan dapat memberikan masukan dan saran atau berbagi knowledge kepada sesama rekan di institusinya. Kegiatan tersebut dilakukan setiap 2 minggu sekali kecuali bila permintaan cukup banyak kolokium dilakukan seminggu sekali. Terbukti dengan pengembangan kolokium yang sudah berjalan antara lain mempresentasikan hasil penelitian dari hibah bersaing UBINUS, usulan penelitian yang akan diajukan ke DIKTI seperti penelitian strategis nasional, presentasi usulan disertasi bagi rekan-rekan dosen yang sedang menjalankan kuliah strata tiga (S3), sharing ide-ide baru.

Secara tak langsung kegiatan ini telah mendorong seseorang menciptakan suatu budaya sharing knowledge bagi yang berpartisipasi. Pembentukan budaya knowledge management yang efektif tergantung pada membentuk waktu dan tempat untuk menciptakan knowledge, berbagi knowledge dan belajar (Davidson \& Voss, 2003). Berawal dari sebuah ide kolokium dengan jumlah orang yang sedikit, kemudian berkembang karena banyaknya permintaan untuk mengisi kegiatan kolokium, dan akhirnya menjadi sebuah kebiasaan. Saat telah menjadi kebiasaan itulah dapat dikatakan sudah kolokium sudah membudaya. Dengan demikian knowledge management mendukung knowledge culture.

\section{Flazz Card}

Secara umum orang mengenal Flazz Card hanya sebatas pengganti uang tunai, dan sebagai pengganti alat pembayaran yang dapat di isi dan digunakan pada merchant-merchant tertentu yang telah bekerja sama dengannya. Semua dosen di BINUS wajib memiliki BINUSIAN Card-Flazz, fungsi BINUSIAN Card-Flazz bagi dosen selain sebagai kartu identitas BINUSIAN, juga berfungsi sebagai kartu diskon yang dapat diterima di merchant - merchant yang telah bekerja sama dengan BINA NUSANTARA. BINUSIAN Card-Flazz bisa digunakan sebagai alat pembayaran multifungsi. Menggunakan teknologi chip dan RFID (Radio Frequency Identification), Kartu Flazz pantas untuk disebut sebagai kartu prabayar multifungsi dengan teknologi terkini.

Pengembangan lebih lanjut, BINUSIAN Card-Flazz dijadikan sebagai kartu identitas dosen yang dapat digunakan sebagai alat pendataan kehadiran dosen saat mengajar. Setiap dosen yang akan mengajar, wajib typing menggunakan Card-Flazz. Data kehadiran dosen tersebut akan diproses lebih lanjut, salah satunya untuk perhitungan honor dosen. Aplikasi yang digunakan untuk menghitung honor adalah Sistem Informasi Honor. Saat dosen telah melakukan absensi menggunakan flazz card, maka data dosen akan terekam di server BINUS. Data dosen tersebut digunakan oleh aplikasi honor untuk penghitungan honor dosen. Setiap tanggal 20 merupakan tanggal cutoff penghitungan honor dosen. Tiap dosen dapat melihat informasi honor melalui binusmaya.

Pengembangan lainnya adalah Flazz card digunakan sebagai alat monitoring keterlambatan dosen. Setiap keterlambatan di rekam pada aplikasi kehadiran, dan informasi tersebut digunakan oleh jurusan untuk mengevaluasi keterlambatan kehadiran dosen. Data kehadiran dosen yang telah tersimpan di server BINUS, digunakan juga untuk menghitung KPI persentase kehadiran dan IKAD dari masing-masing dosen.

Pengembangan selanjutnya adalah Card-Flazz digunakan sebagai tanda masuk parkir mobil. Setiap dosen yang membawa mobil wajib melakukan typing saat memasuki gerbang masuk BINUS. Setiap dosen yang menggunakan flazz card tidak dipungut biaya, karena semua dosen yang membawa mobil dan yang telah didaftarkan di secure parking, maka dibebaskan dari biaya parker. Itu merupakan layanan khusus dosen saat parkir mobil. Selain itu flazz card dapat juga digunakan sebagai identitas untuk pinjam buku di perpustakaan, dan debit pembayaran denda peminjaman buku. Setiap dosen 
yang ingin meminjam buku di perpustakaan, wajib membawa flazz card. Tanpa flazz card maka dosen tidak dapat meminjam buku. Aplikasi peminjaman buku akan mencatat siapa yang meminjam dan kapan batas waktu pengembalian. Sebelum batas waktu peminjaman buku berakhir, maka secara otomatis aplikasi akan mengirimkan e-mail ke dosen untuk mengingatkan berakhirnya batas waktu peminjaman buku. Ini juga merupakan peningkatan layanan bagi dosen yang mengajar di BINUS. Selain itu juga flazz card berfungsi sebagai kartu diskon, E-Wallet.

Flazz Card merupakan sebuah knowledge. Bermula dari kehadiran yang ditulis pada selembar kerja menjadi elektronik. Perubahan budaya absensi berjalan secara bertahap, sampai institusi yakin bahwa pendataan secara electronik ini tidak bermasalah. Dengan kata lain, perubahan proses ini sangat dinamis, dan merupakan strategi baru dalam memecahkan masalah pendataan kehadiran. Di sinilah nampak bahwa knowledge management mendukung dalam menerapkan knowledge culture.

\section{PENUTUP}

Proses terbentuknya sebuah culture baru ataupun perubahan dari sebuah culture yang buruk menjadi culture yang baik membutuhkan waktu yang cukup panjang. Pengembangan Knowledge Management berbasiskan Talent Management merupakan strategi untuk mendukung terbentuknya knowledge culture. Strategi-strategi di atas merupakan sebuah knowledge, yang telah di atur sedemikian rupa yang akhirnya membentuk sebuah knowledge culture. Pendekatan kebijakan, pemberian award kepada karyawan merupakan cara yang baik dalam penerapan knowledge management untuk mendukung knowledge culture. Perlu pengembangan lebih lanjut khususnya pendokumentasian knowledge manajement agar dapat dengan mudah di akses oleh setiap unit atau setiap orang yang relevan guna tidak terulangnya masalah yang sama.

\section{DAFTAR PUSTAKA}

Davidson, C., \& Voss, P. (2003) Knowledge management: An introduction to creating competiton advantage from intellectual capital. Vision Book New Delhi.

Hamid, Z. A. (2008). Identifying knowledge and creating knowledgeable employees. Journal of Knowledge Management Practice, Vol. 9, No. 2, June 2008.

Kuruganti, $\quad$ M. $\quad$ S. $\quad$ (n.d.). Peran SDM dalam Melembagakan Manajemen Pengetahuan di sebuah Perusahaan. Diakses pada 12 Mei 2011, dari: http://kwork.org/White_Papers/hr-km.html

McAdam, R., \& Reid, R. (2000). A comparison of public and private sector perceptions and use knowledge management. Journal of European Industrial Training, 24(6), 317-329.

Nonaka, I., \& Takeuchi, H. (1995). The knowledge creating company. New York: Oxford University Press. 